\title{
The Comparative Study of the Relationship Between Smartphone Choice and Socio-Economic Indicators
}

\author{
Maral Jamalova ${ }^{1}$ \& Constantinovits Milán ${ }^{1}$ \\ ${ }^{1}$ Szent István Egyetem, Gödöllő, Hungary \\ Correspondence: Maral Jamalova, Szent István Egyetem, Gödöllő, Páter Károly utca 1, Hungary. E-mail: \\ mjamalova@hotmail.com
}

Received: January 31, 2019

Accepted: March 13, 2019 Online Published: July 12, 2019

doi:10.5539/ijms.v11n3p11

URL: https://doi.org/10.5539/ijms.v11n3p11

\begin{abstract}
The aim of the current study is to measure the influence of the socio-economic indicators on consumers' purchase decision about smartphones based on the operating system. For this purpose, indicators as GDP per capita, Gross Savings, Inflation, ICT Development Index, Unemployment and Human Development Index were chosen. Excluding cultural, psychological and personal factors (which mainly should be analyzed on microeconomic level), therefore mentioned socio-economic variables are the same for all citizens of the country. These indicators create an overview of the general situation on the global level and in the developing/developed countries. Also, it makes a sense to identify the relationship between variables not only on the global level but also in the context of income level. So, research is essential to determine the above-mentioned trends in the smartphone market.
\end{abstract}

Keywords: smartphone, smartphone market, socio-economic indicators

\section{Introduction}

Nowadays mobile phones are necessities of the individuals' life. Mobile/cellular phones together with computers are the main elements of the 4th technological revolution which began in the USA and spread all over the world. Recently, smartphones are one of the main ways of staying in touch with friends, colleagues, relatives, and neighbors. Additionally, consumers use different services and applications (such as a mobile bank, some health applications, traveling/hotel booking, and maps, etc.) which made the handsets irreplaceable parts of everyday life.

Rapid technological development at the beginning of the 2000s caused significant changes in handsets: battery lifetime and standby time increased; multimedia message service (MMS) and global positioning system (GPS) were activated; the $3 \mathrm{G}$ network was neglected, etc. Consequently, the internet connection and technological features changed the development direction of the mobile phones, and, the smartphone era began. As a result of the technical improvement, the operating system of smartphones and some other features became more essential for consumers.

An operating system (OS) is the main software which manages wireless and cellular networks and phone number features. Also, the operating system is a software on which individuals install different programs and/or applications. Unfortunately, there is no data related to the smartphone OS market share in 2007-2008 years. Comparison of market share in 2009 and 2017 shows that the situation in the market is different. In 2009, iOS (smartphones produced by Apple Inc.) BlackBerry OS (devices with same brand name produced by RIM) and Symbian OS (OS developed by Psion, Nokia, Ericsson, and Motorola) were more frequently used OSs all over the world. In 8 years, the market share of smartphones with Symbian and BlackBerry OS decreased significantly from $35.49 \%$ and $8.16 \%$ to $0.21 \%$ and $0.3 \%$ respectively. Market share of iPhones decreased from 34.01\% to $19.65 \%$, when the market share of Android-based smartphones increased from around 3\% to $72.63 \%$ (Source: http:/gs.statcounter.com/os-market-share/mobile/worldwide/\#yearly-2017-2017-bar accessed the 25th of January, 2019). Therefore, nowadays iOS and Android are the two main market players.

Smartphone choice is a complicated behavior of consumers which actually cannot be analyzed by studying the relationship between some socio-economic variables and OS market share. Generally, consumer behavior toward smartphones includes cultural, social (or socio-economic) psychological factors (Jamalova \& Fehér, 2018). The 
current study, considering only socioeconomic variables, will give only information about general movements without a deep understanding of the reasons for behavior. For more detailed results, each country should be analyzed separately with taking into consideration the above-mentioned factors. For predicting the behavior of smartphones users, TAM, extensions or alternative models are useful (Galib, Hammou, \& Steiger, 2018).

\section{Review}

From the infrastructure point of view, the smartphone industry faced "leapfrog" (from the 20th century to the $21 \mathrm{st}$ century) in the developing countries according to the Economist (https://www.economist.com/leaders/2008/02/07/the-limits-of-leapfrogging accessed 12 November 2018). Economic aspects of the notion were explained in the research of the World Bank. The research proves that technological development finds the way to decrease infrastructure costs (World Bank, 2008). Moreover, in some of the countries, smartphone infrastructure was created by "well-funded private operators" (http://documents.worldbank.org/curated/en/827331468323971985/Global-economic-prospects-2008-technology -diffusion-in-the-developing-world accessed 12 November 2018). By contrast, in other countries, the procedure of getting licenses for mobile communication services decreased the speed of the spreading of mobile technologies in 2007 (Sullivan, 2007).

The smartphone diffusion comes from an understanding of the diffusion theory. P. Deutschman and W. Danielson were the first scientists who captured attention to the knowledge diffusion in summer 1960 (Deutschmann \& Danielson, 1960). Rogers published the first book "Diffusion of innovation" in 1962. He enriched and complicated the theory of innovation diffusion. For the author, the diffusion is a process where innovation is used (originally, communicated) by consumers (originally, social system) through some channels (Rogers, 2003). According to the theory, the population was divided into five groups as innovators, early adopters, early majority, late majority, and laggards (Rogers, 2003). He created the innovation diffusion curve which shows the relationship between penetration rate and time. It was called the S-shaped curve as the curve resembles "S". The curve generally was applied to illustrate the situation in the developed countries (James, 2015). However, the situation in developed and developing countries is completely different.

Moreover, Rogers discussed five main characteristics of Innovation Diffusion which have an impact on innovation penetration. They are relative advantage, compatibility, complexity, trialability, and observability (Rogers, 2003). From cellular phones point of view, E. Rogers studied these characteristics (in "Cellular Telephones and Lifestyle Revolution" case study) in his book in 2003. However, the industry and technologies faced significant change after 2003. Later different researchers applied the innovation characteristics in order to investigate the adoption of smartphones in the country and cross-cultural level (Arpaci, Cetin, \& Turetken, 2015; Park \& Chen, 2007). Nowadays, considering the importance of OS for smartphone users, below the main characteristics of innovation diffusion are explained from OS point of view.

Table 1. Characteristics of the smartphone innovation diffusion according to OS

\begin{tabular}{lll}
\hline $\begin{array}{l}\text { Characteristics of the } \\
\text { Innovation Diffusion }\end{array}$ & iOS & Android \\
\hline $\begin{array}{l}\text { Relative advantage } \\
\text { (economic and social } \\
\text { aspects) }\end{array}$ & $\begin{array}{l}\text { The relative advantage of iOS-based smartphones is } \\
\text { characterized by social aspect according to the } \\
\text { character of the users. The purchase of iPhone has } \\
\text { mainly "status-conferring" intention. }\end{array}$ & $\begin{array}{l}\text { The relative advantage of Android-based smartphones is } \\
\text { characterized by economic aspect based on the income } \\
\text { level of the users. The purchase decision of Android is } \\
\text { supported by the economic interests of the buyer. }\end{array}$ \\
\hline Compatibility & $\begin{array}{l}\text { Innovations are compatible in the case of iOS as they } \\
\text { do not oppose "sociocultural values/believes" and } \\
\text { "previously introduced ideas". These smartphones } \\
\text { always satisfy end users from developed and } \\
\text { developing countries with numerous innovations. }\end{array}$ & $\begin{array}{l}\text { Android owners are also consistent with smartphone } \\
\text { innovations in "sociocultural values/believes" and } \\
\text { "previously introduced ideas" context. However, } \\
\text { expectations of users from developing countries toward } \\
\text { device are not so high as in developed countries. }\end{array}$ \\
\hline $\begin{array}{ll}\text { iPhone handset owners argue about simplicity (or } \\
\text { ease to use as mentioned in TAM) of the device. }\end{array}$ & $\begin{array}{l}\text { Androids are not so complex devices however they seem } \\
\text { to be complicated in comparison with iPhones. }\end{array}$ \\
\hline $\begin{array}{l}\text { Trialability } \\
\text { Trialability of iOS-based devices is harder as they are } \\
\text { not so affordable in the case of emerging economies. }\end{array}$ & $\begin{array}{l}\text { Trialability of the Android-based handsets is easier as they } \\
\text { are cheaper and more affordable for the buyers from } \\
\text { developing countries. It increases the number of } \\
\text { individuals who are able to try it. }\end{array}$ \\
\hline $\begin{array}{l}\text { Observability } \\
\text { (hardware and } \\
\text { software aspects) }\end{array}$ & $\begin{array}{l}\text { iOS are leading in the terms of the design or } \\
\text { hardware. However, it is evident that, in software } \\
\text { case, iOS users have no so much alternatives to } \\
\text { choose from. }\end{array}$ & $\begin{array}{l}\text { Android producers try to compete, and they create } \\
\text { better-designed handsets. However, there are a lot of } \\
\text { applications for these devices and it is one of the } \\
\text { advantages of having an Android. }\end{array}$ \\
\hline
\end{tabular}

Source: Own compilation based on Rogers, 2003. 
Roger's Theory about Innovation Diffusion is essential for analyzing the smartphone market at the country and global level (López-Nicolás, Molina-Castillo, \& Bouwman, 2008). Moreover, others dealing with the diffusion (of innovations) in the mobile phone market showed that, the S-shaped curve offered by Rogers behaves differently in the developing countries (Bento, 2012; James, 2015; Kalba, 2008). James came to the conclusion that, in developing countries innovations slowly entered the life of consumers. Results of "Smartphone user segmentation by engagement pattern" in 2017 (part of the report p. 17, GSMA, 2018a) confirm the above-mentioned idea. Early adopters and early majority show high numbers in North America $(53 \%$ and $36 \%$ respectively) and Europe ( $46 \%$ and $42 \%$ respectively) which explains that, the diffusion of technologies in these countries happens faster (GSMA, 2018a).

Additionally, in the last book written by Rogers in 2003, the author explained the idea that, individuals' reaction to the new technologies/innovations is highly related to socioeconomic status (Rogers, 2003). Moreover, socioeconomic status influences mobile phone purchase. Therefore, the level of socioeconomic development creates a basis for "affordability" and/or in some literatures "capability" (Todaro \& Smith, 2015). Even if affordability is not clearly an economic term it creates imagination about consumer's expectations toward product and consumer's financial situation. Briefly, affordability/capability is the amount of money an individual would like to pay for a service or equipment. In the case of low-income countries "economic constraint" and underdevelopment causes low affordability level (Donner, 2009). Affordability level of smartphone owners from countries in different income groups is not the same (GSMA, 2017). Moreover, the price of the handset which individuals can afford also varies among the geographical areas (Abdel-Wahab \& El-Masry, 2011; Fenn, 2013; James, 2014). Some authors agreed that, cheap prices of devices and smartphone services made them more attractive to consumers in developing countries as it increases their affordability potential (Bento, 2012; GSMA, 2017).

According to the results of the literature review, it is evident that, there is a quite big gap between developing and developed countries in terms of innovation diffusion. Socioeconomic reasons like the low quality of education and health care, illiteracy, lack of jobs, bureaucracy, the dependence of the economy on raw materials, political instability and other factors slow down the innovation diffusion process. Nowadays, smartphones are frequently used electronic devices and they are becoming an essential part of the innovation diffusion process. Therefore, it is essential to measure the relationship between socio-economic (including technical infrastructure) indicators and market share of smartphones. The measurement can explain some economic reasons for consumers' behavior in developing and developed countries, provides an insight into the differences in affordability level according to income, defines advantages/disadvantages of some economic indicators etc.

\subsection{The Current Situation in the Smartphone Market}

At the end of 2018, the number of mobile phone subscriptions reached more than 5.2 billion according to GSMA website (https://www.gsma.com/\#sdgs accessed the 14th of January 2019. GSM Association which is a trade body founded in 1995 in order to support usage of GSM technologies by mobile operators. Currently it connects more than 750 mobile operators and 350 companies which belong to the same industry). Moreover, it is a high result in comparison with any other existing technology (GSMA, 2018a). According to the World Bank, penetration rates in Europe, Central Asia, Latin America, and the Caribbean were high enough in 2008. Mobile phone industry also had stable growth after 2000 in developing countries (Bento, 2012). Price of Androids decreased significantly from 2008, which is one of the main reasons for the steady increase in demand in developing countries (Table 1). Additionally, by the end of 2017, penetration rate in $30 \%$ of the world's countries (including well developed European countries, US, Russia, and Japan) reached 85\% (GSMA, 2018a). In the same year, $59 \%$ of consumers all over the world were owners of smartphones, but for developing markets the value of the indicator was only 55\% (GSMA, 2018b) when for Northern America it was 80\% (GSMA, 2018a).

According to the statistical results of 2017 more than $90 \%$ of purchased smartphones have Android or iOS operational system. But the main competitors are Apple and Samsung. 19\% of all smartphones sold in the world in 2016 were manufactured by Apple Inc. On the smartphone market, the share of Samsung is higher in comparison with Apple and around one-third of the world decided to buy Galaxy smartphones in 2016. Market share of Nokia was $6 \%$, LG $4 \%$, and Huawei $3 \%$ in the same year. According to the reports of several organizations, Huawei increased sales in the second quarter of 2018 (https://www.theguardian.com/technology/2018/aug/01/huawei-beats-apple-smartphone-manufacturer-samsungipho a|ne accessed the 14th of January, 2019). There was a small fluctuation in the market share of Apple and Samsung at the end of 2018. But it is surprising that, Huawei and Xiaomi increased their market share by almost $6 \%$. The reason can be the cheaper price of their devices which increases the affordability level of consumers. 


\subsection{1 iOS/iPhone}

The first iPhone was introduced in the middle of 2007. Surprisingly around 1.4 million handsets were sold worldwide until the end 2007 (https://www.statista.com/statistics/276306/global-apple-iphone-sales-since-fiscal-year-2007/ accessed on the 25th of January, 2019). The company created a mobile operating system based on an own desktop OS (later called iOS) and it is used only for Apple Inc. products. iPhone was the pioneer on the smartphone market by connecting the touch screen, access to the internet and easy-to-use platform. For simplifying music listening services, the company introduced iTunes (Bresnahan \& Greenstein, 2014). Later in 2008 the company launched the App Store and gave the opportunity to independent developers to create their own applications on the Apple based OS. The company strengthens the position in the safety and quality terms by strictly controlling all applications represented in the App Store (Bresnahan \& Greenstein, 2014; Hazlett, 2011). Apple receives $30 \%$ commission for each download of approved paid applications and in-application purchases and the first year of subscriptions which is high enough according to developers (https://www.igeeksblog.com/app-developers-oppose-app-store-commission-rate-22082018/ accessed the 25th of January, 2019).

According to the financial report of Apple Inc. in 2018 more than 217 million smartphones were sold and net iPhone sales were more than 166 billion USD (Apple Inc., 2018). Nowadays, smartphone line of Apple Inc. includes not only newly introduced iPhone X, iPhone XS, XS Max, and XR but also iPhone 7, 7 Plus, 8 and 8 Plus (Apple Inc., 2018). Excluding the first quarter of 2016 and the second quarter of 2017, all top 5 smartphones in Asia were manufactured by Apple Inc. In the first quarter of 2016 and the first and third quarter of 2017, 4 from 5 top smartphones in Asia belonged to Apple incorporation. In Europe, 3 from 5 top smartphones were different versions of iPhone in 2016, and in 20174 out of 5 smartphones belonged to Apple. In the first, the second and the third quarter of 2018 (ScientiaMobile, 2018b, 2018a, 2018c), 4 from top 5 smartphones in Asia and in Europe were smartphones designed and manufactured by Apple Inc. In North America, from the third quarter, Apple Inc. got all the places in the top 5 smartphones list. However, the position of the iPhones is not so strong in South America and Africa. In Oceania, a number of Apple smartphones among Top 5 fluctuates between 4 and 5 over the period shown.

Regarding the innovation diffusion, handsets manufactured by Apple Inc. use leading-edge technologies. Each year the company tries to introduce the smartphone by applying the latest innovations, upgrading OS and widening technical features. Application of innovations also cause expensive prices of the devices; however, the company intends to keep leadership in the market by making the new devices more attractive not only from the technical side but also from the design point of view.

\subsubsection{Android}

Android is a Linux based OS which was developed by Android Inc. that was later bought by Google. In 2007 the company announced the establishment of Open Handset Alliance (OHA) for the development of open standards for different types of mobile devices. According to the agreement, OHA members can produce mobile devices working on Android OS. Smartphone producers such as HTC, LG, Sony, Samsung etc. are members of OHA and these companies use Android OS. The usage of Android OS is licensed for producers but OHA members use it in handsets free of charge (https://www.wired.com/2008/06/ff-android/ accessed the 25th of January, 2019). Additionally, Google followed a different strategy in comparison with iOS, and in Google Market, there is not so strict regulation of the content and applications which sometimes may cause failures (Hazlett, 2011). It also creates a positive competition environment and an opportunity to reach more applications and to choose among them. However, Google also has 30\% application commission for third-party providers (Hazlett, 2011).

Table 2. The average selling price of smartphones by operating system

\begin{tabular}{|c|c|c|c|c|c|c|c|c|c|c|}
\hline Year & 2007 & 2008 & 2009 & 2010 & 2011 & 2012 & 2013 & 2014 & 2015 & 2016 \\
\hline Average Selling Price of iOS (Apple) & $\$ 594$ & $\$ 621$ & $\$ 623$ & $\$ 703$ & $\$ 712$ & $\$ 686$ & $\$ 669$ & $\$ 680$ & $\$ 716$ & $\$ 690$ \\
\hline Average Selling Price of Android (Google) & - & $\$ 403$ & $\$ 435$ & $\$ 441$ & $\$ 380$ & $\$ 318$ & $\$ 272$ & $\$ 237$ & $\$ 217$ & $\$ 214$ \\
\hline
\end{tabular}

Source: IDC Worldwide Mobile Phone Tracker, 2017 (IDC, 2017).

OS of devices is one of the first technical features which consumer decides about. Androids are widespread, cheap and affordable for each consumer. Because of different manufacturers, Android smartphone line becomes quite extensive. The innovation diffusion in the case of Androids differs from iPhones. The price category of 
smartphones, technical parameters, manufacturers also differ. Usual cheap basic models are customized for middle or low-income consumers. These handsets are not specifically innovative. The average selling price of Androids was around \$214 in 2016 (Table 1). They almost have no advanced features which require research and development tasks. However, expensive Android-based smartphones which compete with iPhones include the results of the latest technological development. The average price of the iPhone was $\$ 690$ in 2016 and models which compete with iPhones are also priced in the same range. It means that, the price of one iPhone or another expensive smartphone is equal to the price of almost 3 average model smartphones. The final decision is in the hands of the consumer. The consumer chooses smartphone according to his/her personal, price, brand and technical preferences.

\subsubsection{Samsung}

The South-Korean Samsung Electronics is one of the largest companies which produces consumer electronics. It also has business divisions such as IT and Mobile Communications and Device Solutions. The company is famous about the Samsung Galaxy line which was globally the first in 2016 according to the mobile phone (19.2\%) and smartphone (20.8\%) market share (Samsung Electronics, 2017). Samsung has a wide range of smartphones, and, consumers from different income groups can afford them. According to the report, the company got a positive response from the consumers of middle/low priced headsets (Samsung Electronics, 2017). Moreover, the most expensive Samsung smartphones (Samsung Galaxy Note Series) are competitors of the last versions of the iPhone.

According to the Mobile Overview Report, in 2016, two of the five top smartphones in Europe were produced by Samsung. Samsung lost the position from 2016 to 2017 and just one Samsung smartphone was among the best ones in Europe in 2017 (Scientiamobile, 2016; ScientiaMobile, 2016b, 2016a, 2016c, 2017b, 2017a). According to the MOVR: Mobile Overview Report, in the first, the second and the third quarter of 2018 (ScientiaMobile, 2018b, 2018a, 2018c), 1 from top 5 smartphones in Asia and in Europe is a smartphone produced by Samsung. These smartphones had strong positions in South America (3 from Top 5 Smartphones) and Africa (1 sometimes 2 from Top 5 Smartphones). Interestingly, the models which are in the Top 5 Smartphone list (in Asia, South America, and Africa) are not the most expensive models which are competing with iPhones. They are low-middle priced smartphones which are affordable for consumers. (For example Galaxy J2/J7 Prime, Galaxy J5, Galaxy Grand Prime +) Competition between expensive Galaxy S7 and S8 models and iPhones is clear only in the case of Europe.

\subsubsection{Huawei}

Originated in China, Huawei increased market share in a short time and continues to grow with high speed. During 2016, Huawei sold smartphones in around 170 countries in the world (Dedrick \& Kraemer, 2017). Unfortunately, there is a lack of data available about Huawei. However, Huawei smartphones are more affordable for consumers because of the combination of cheap price and good quality. Huawei smartphones compete with iPhone in the list of top smartphones in the 2017 and 2018 years (ScientiaMobile, 2017b, 2017a, $2018 \mathrm{~b}$ ) and it was the third most popular smartphone brand in France and Croatia (ScientiaMobile, 2018c).

\section{Methodology}

This study aims to discover relationships between some economic development indicators and smartphone sales by OS in developed and developing countries. There are two main operating systems which are widespread everywhere in the world and around $85-90 \%$ of all sold smartphones are based on one of them. For the sake of a more compact analysis of the market share of smartphones by the operating system, iOS and Android were chosen for further analysis.

There was no sufficient data about the year 2017. This is the reason why all used data expresses the information from 2016. Overall, data from 189 countries were analyzed using the SPSS statistical data editor. All countries which have a data on the IDI (ICT Development Index created by the International Telecommunication Union; the specialized agency of the United Nations) value were chosen for the analysis. According to the results of the normality test (Kolmogorov-Smirnov and Shapiro-Wilk tests, and scatterplot charts), the values of the indicators were not normally distributed. Therefore, Spearman's rank correlation method was chosen instead of the Pearson correlation. Results of the analysis are valid if the null hypothesis could be rejected and the significance level is below 0.01 ( $\mathrm{p} \leq 0.01$ in some cases $0.05 / \mathrm{p} \leq 0.05$ ). The general form of a null hypothesis for a Spearman correlation is:

\section{Hypothesis 0: There is no relationship between the ranks based on two variables.}

In order to understand the hidden intercorrelations, the so-called moderator variable was involved. The 
moderator variable is the income level of countries according to the classification of the World Bank (https://datahelpdesk.worldbank.org/knowledgebase/articles/378832-what-is-the-world-bank-atlas-method accessed the 25th of January, 2019). Each year Word Bank classifies countries in four groups based on the level of GNI (https://blogs.worldbank.org/opendata/new-country-classifications-2016). Groups are: 'low' (29 countries in 2016), 'lower-middle' (50 countries in 2016), 'upper-middle' (53 countries in 2016) and 'high' (56 countries in 2016) income levels. For the current analysis, low, lower-middle and upper-middle income group countries were summarized as developing countries. High-income countries were considered as developed countries. Countries were filtered according to the groups.

\section{Hypothesis Development}

Socio-economic development is a complex process which is the result of the right economic, social and political course. Variables of economic development were chosen based on the literature review. Also, on the macroeconomic level, these indicators might be considered as key points to analyze consumer behavior.

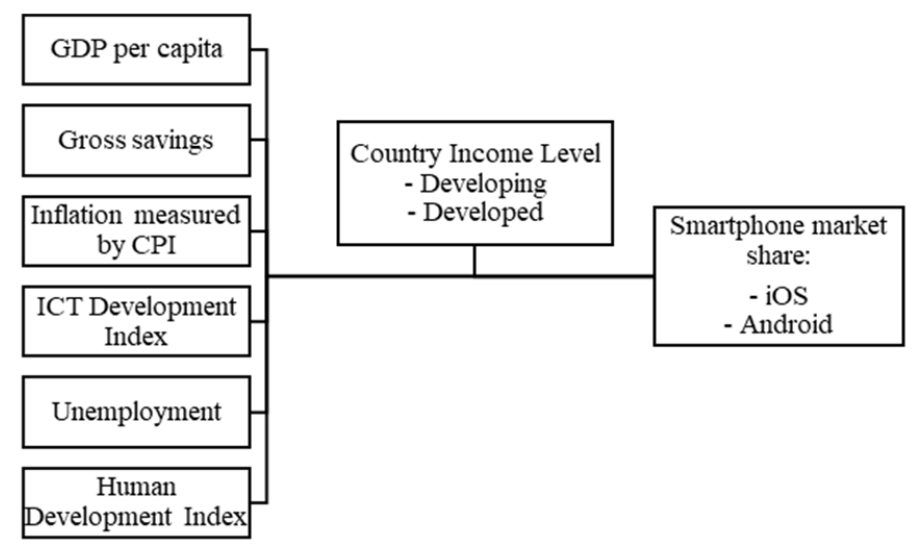

Figure 1. Hypothesis development

Source: Own editing based on literature review.

For measuring economic development, researchers usually use theoretically widely accepted indicators like GDP and/or GNI. Historically, some authors argue that, measuring economic development just with GDP/GNP has some limitations. It is a strong argument as the market value of final goods and services produced inside the country cannot create a vision about development. At large, development is a combination of economic indicators and key elements like health-care, education, freedom of speech, gender equality etc. Also, indicators such as unemployment, HDI, IDI value and inflation can create a better overview of the economic development of the country. Moreover, complex indicators such as HDI are essential for capturing more complex themes (Bálint \& Tóth, 2018). In this research, the above-mentioned indicators will be taken into consideration from an economic point of view.

Moderator Variable-Income level

Income is one of the crucial factors for defining and justifying the main reason for the purchasing power of citizens at the country level. It is the key element characterizing the affordability/capability of the smartphone owners. Income level was the main explaratory variable in the research which shows differences in the diffusion of mobile phones in rural areas of Africa, Asia and all countries across the world (Kalba, 2008). It was also used for understanding the contribution of mobile telecommunications to economic growth (Gruber, Koutroumpis, Mayer, \& Nocke, 2011). Furthermore, the income level was used by GSMA for explaining the purchasing power of smartphone users from emerging markets (GSMA, 2017). According to the results of Pew Research Center (http://www.pewresearch.org/fact-tank/2017/04/21/smartphones-are-common-in-advanced-economies-but-digital -divides-remain/) and the author of "Smartphone paradox" book, income and education level are key indicators for defining smartphone ownership among consumers (Reid, 2018). Researchers used the income level together with GDP and mobile penetration rate in order to identify mobile phone diffusion in developing countries. According to previous studies, the income level is the major moderator variable for analyzing the relationship between the macroeconomic indicators and mobile phone vendors' market share. 


\section{H1: GDP per capita}

According to the examples from the telecommunication sphere, $10 \%$ increase in telecommunication penetration rate causes $2.8 \%$ growth of the GDP in 21 OECD countries (Roller \& Waverman, 2001). The same research in developing countries showed that, if mobile phone penetration would increase by 10 mobile phones per each of 100 people, it would add 0.59\% GDP growth (Waverman, Meschi, \& Fuss, 2005). In 2017, 4.5\% of global GDP originated from mobile technology sales and services and it means that, $\$ 3.6$ trillion added economic value (GSMA, 2018a). Only in Europe the contribution of mobile technologies to GDP was around $€ 550$ billion which is $3.3 \%$ of the total GDP. Previously, authors examined correlation between per capita GDP and mobile phone penetration rate from 1990 to 2007 in 192 countries and the correlation coefficient was 0.56 (Gruber et al., 2011).

Table 3. Descriptive statistics

\begin{tabular}{|c|c|c|c|c|c|c|}
\hline Variables & $\begin{array}{l}\text { Countries/ } \\
\text { observation }\end{array}$ & Minimum & Maximum & Mean & $\begin{array}{l}\text { Std. } \\
\text { Deviation }\end{array}$ & Data source \\
\hline $\begin{array}{l}\text { GDP per capita } \\
2016 \text { (in USD) }\end{array}$ & 188 & $\$ 0.00$ & $\$ 100,739$ & $\$ 12,379$ & $\$ 17,419$ & $\begin{array}{l}\text { World Bank } \\
\text { (https://data.worldbank.org/indicator/NY.GDP.PCAP.CD } \\
\text { the 2nd of January, 2019) }\end{array}$ \\
\hline $\begin{array}{l}\text { Gross savings } 2016 \\
\text { (\% of GDP) }\end{array}$ & 189 & -13.40 & 56.41 & 16.47 & 12.93 & $\begin{array}{l}\text { World Bank } \\
\text { (https://data.worldbank.org/indicator/NY.GNS.ICTR.ZS } \\
\text { the 2nd of January, 2019) }\end{array}$ \\
\hline $\begin{array}{l}\text { Inflation measured } \\
\text { by CPI } 2016\end{array}$ & 189 & -3.09 & 379.85 & 6.52 & 33.43 & $\begin{array}{l}\text { World Bank } \\
\text { (https://data.worldbank.org/indicator/FP.CPI.TOTL.ZG } \\
\text { the 2nd of January, 2019) }\end{array}$ \\
\hline IDI 2016 & 174 & .89 & 8.80 & 4.89 & 2.22 & $\begin{array}{l}\text { ITU (https://www.itu.int/net } 4 / \text { itu-d/idi/2017/index.html } \\
\text { the 2nd of January, 2019) }\end{array}$ \\
\hline $\begin{array}{l}\text { Unemployment } \\
2016(\% \text { of labour } \\
\text { force })\end{array}$ & 189 & 0.00 & 27.80 & 7.46 & 6.10 & $\begin{array}{l}\text { World Bank } \\
\text { (https://data.worldbank.org/indicator/SL.UEM.TOTL.ZS } \\
\text { the 2nd of January, 2019) }\end{array}$ \\
\hline $\begin{array}{l}\text { Human } \\
\text { Development Index } \\
\text { (HDI) } 2016\end{array}$ & 189 & 0.000 & .951 & .70 & .16 & $\begin{array}{l}\text { UN (http://hdr.undp.org/en/data } \\
\text { the 2nd of January, 2019) }\end{array}$ \\
\hline
\end{tabular}

Source: Own editing based on the study

\section{$\mathrm{H} 2$ : Gross savings as a percentage of GDP}

The explanation given on the website of the World Bank defines gross savings as the difference between disposable income and consumer's consumption. Gross savings are essential because of several reasons. First, saving indicates the financial status of consumers and also identifies the affordability level. At micro-level, savings are consumers' financial reserves, while in macro level it is one of the factors which contribute to the development of national economies (Azariadis \& Drazen, 1990; Domar, 1946; Griffin, 1970). Thus, savings in macro-level result in opening up new companies and ultimately strengthening the economy. As for the smartphone market, gross savings are important on the micro level. Logically, saving is one of the factors that can affect the consumer's choice of smartphones. It is evident that, in low-income countries (such as African countries, Aker \& Mbiti, 2010), if the consumer decides to buy an expensive smartphone, partly/fully it is financed by savings and/or credits (Pádraig, 2012).

H3: Inflation measured by the Consumer Price Index

Consumer Price Index (CPI) plays an important role in this study as it determines inflation based on the consumer basket. Moreover, it is evident that, at different levels, inflation can cause different consequences for the national economy. High level of inflation is dangerous for the country's economy, as well as in micro level it causes uncertainty for consumers. Logically, high inflation has a negative impact on the sales of expensive phone models. So, it is inevitable to identify the relationship between inflation and the iOS/Android market share. Numbers were downloaded from the World Bank database (https://data.worldbank.org/indicator/FP.CPI.TOTL.ZG). 


\section{H4: ICT Development Index}

ICT Development Index, shortly IDI began to be published from 2009 by ITU - specialized agency of the UN. The index is used to make observations and comparisons among countries. IDI is a combination of 11 indicators in 3 sub-indexes: ICT access, ICT use, and ICT skills. IDI includes information regarding essential variables such as smartphone subscription, the percentage of individuals using the Internet, mean years of schooling etc. Several scientists conduct researches in order to identify the most relevant variables and validity of ICT Development Index (Dobrota, Jeremic, \& Markovic, 2012; James, 2012). The main purpose of adding this index to the research is to determine the level of innovation diffusion in developing countries.

\section{H5: Unemployment rate (percentage of the total labor force)}

Employment is one of the key factors of economic growth and development. The more workplaces the country has, the faster the economy grows. Moreover, employment creates a financial basis for smartphone purchase. (Karjaluoto et al., 2005; Mackay \& Weidlich, 2014) Logically, individuals with high salary choose more expensive handsets. From another side, development of telecommunication industry also creates jobs. According to the results of GSMA, mobile operators directly employed around 12 million people all over the world in 2017 (GSMA, 2018a). However, in developing world there are mainly retail-specific jobs such as Sim card, Handset sales and etc. (Dyer-Witheford, 2015).

\section{H6: Human Development Index}

Human Development Index (abbr. HDI) is the composite index created by the UN in 1990 which includes Life Expectancy and Education indices and GNI per capita. High HDI means that, the citizens of the country have the opportunity to live a long and healthy life with high access to knowledge. The below mentioned indices make HDI essential for understanding consumers' purchase decision toward smartphones. However, research conducted to examine the relationship between mobile phone subscription/internet subscription and HDI in Africa identified that, there is a positive and strong link between variables (Njoh, 2018). So, the relationship between HDI and iOS/Android market share can explain also a relationship with elements of HDI such as life expectancy and education.

\section{Results and Discussion}

\subsection{Android OS}

Overall, there is no relationship between GDP per capita and Android market share (Hypothesis 1). However, countries are divided into two groups according to the moderator variable, and results are surprisingly different. In Developing Countries purchase decision of the Android-based smartphones is correlated with GDP per capita in a positive way. The strength of the correlation is moderate $\left(r_{s}=0.396\right)$. Probably Low Income (according to UN classification GNI less than \$1000) and Lower Middle-Income (GNI between $\$ 1000$ than $\$ 4000$ ) countries decrease the strength of the correlation. In such weak economies, consumer's income is low, and the standard of life is so inferior that, individuals cannot even purchase the smartphone which costs more than $\$ 200$. Also, in these countries, smartphone penetration is lower than the world average which proves that, technology diffusion faces problems mainly because of the low-income level and poverty.

By contrast, in developed countries, the situation is contrary different. Market share of Androids is correlated negatively with GPD per capita which is opposing to the above-explained notion. For developed countries, the correlation coefficient value $\left(\mathrm{r}_{\mathrm{s}}\right)$ is -0.668 , which could be considered as strong correlation as well. Results indicate that, Android-based devices are not so attractive for consumers from developed countries.

Surprisingly, neither in developing nor in developed countries, consumers' decision towards Android-based smartphones are not connected with Gross Savings as the percentage of the GDP and Inflation measured by CPI (Hypothesis 2-3). Nowadays, smartphones became one of the devices which are basically highly demanded. The prices of handsets also decreased, and they are more affordable for consumers. Compared to the iOS-based smartphones, Androids are cheaper, and the same applications can be easily installed to Android OS-based smartphones. Logically, it does not contain so much risk to decide about any cheap product. Moreover, to be available any time, to be aware of everything that happens around is one of the main trends of the present-days. So, the device somehow becomes first need equipment, that even inflation cannot affect consumers' purchase intention. It is one of the evident reasons of "leapfrog" of the smartphone industry. According to the results of the GSMA report in Sub Saharan Africa (mainly, countries with low GDP and Gross saving and high inflation), smartphone adoption is overall $34 \%$, and subscriber penetration is $44 \%$. It is the region with the lowest values of indicators in the world, but one-third of the population uses smartphones. 
IDI value reveals ICT access, use, and skills (Hypothesis 4). Logically, the indicator reaches the top in developed countries and the bottom in the developing ones. Worldwide, Android market share and IDI value are negatively correlated (Hypothesis 4). Correlation coefficient value $\left(\mathrm{r}_{\mathrm{s}}\right)$ is -0.142 and the absolute value of the correlation coefficient is less than $0.2\left(\left|\mathrm{r}_{\mathrm{s}}\right|<0.2\right.$, normally weak correlation is considered to fall between 0.3 and 0.5$)$. Briefly, it means that, the relationship between variables is weak but significant and negative. So, generally, IDI score means that the market share of Android smartphones is low all over the world.

Table 4. Results of the analysis

\begin{tabular}{|c|c|c|c|c|}
\hline $\begin{array}{l}\text { Hypothesis 1: } \\
\text { There is a relationship } \\
\text { between smartphones } \\
\text { market share and GDP } \\
\text { per capita. }\end{array}$ & Android & $\begin{array}{l}\text { Confirmed } \\
\text { Confirmed } \\
\text { Confirmed } \\
\text { Rejected } \\
\text { Confirmed } \\
\text { Confirmed }\end{array}$ & $\begin{array}{l}\text { All } \\
\text { Developing } \\
\text { Developed } \\
\text { All } \\
\text { Developing } \\
\text { Developed }\end{array}$ & $\begin{array}{l}r_{s}=0.728 ; p \leq 0.01 ; p=0.00 ; n=186(\text { positive and strong) } \\
r_{s}=0.588 ; p \leq 0.01 ; p=0.00 ; n=130 \text { (positive and moderate) } \\
r_{s}=0.703 ; p \leq 0.01 ; p=0.00 ; n=56 \text { (positive and strong) } \\
r_{s}=-0.075 ; p=0.308 n=187 \text { no relationship } \\
r_{s}=0.396 ; p \leq 0.01 ; p=0.00 ; n=131 \text { (positive and moderate) } \\
r_{s}=-0.668 ; p \leq 0.01 ; p=0.00 ; n=56 \text { (negative and moderate) }\end{array}$ \\
\hline $\begin{array}{l}\text { Hypothesis } 2 \text { : } \\
\text { There is relationship } \\
\text { smartphones market } \\
\text { share and Gross } \\
\text { Savings. }\end{array}$ & Android & $\begin{array}{l}\text { Confirmed } \\
\text { Rejected } \\
\text { Rejected } \\
\text { Rejected } \\
\text { Rejected } \\
\text { Rejected }\end{array}$ & $\begin{array}{l}\text { All } \\
\text { Developing } \\
\text { Developed } \\
\text { All } \\
\text { Developing } \\
\text { Developed }\end{array}$ & $\begin{array}{l}r_{s}=0.282 ; p \leq 0.01 ; p=0.0 ; n=187 \text { (positive and weak) } \\
r_{s}=0.167 ; p=0.056 ; n=131 \text { no relationship } \\
r_{s}=0.234 ; p=0.082 ; n=56 \text { no relationship } \\
r_{s}=-0.068 ; p=0.351 n=188 \text { no relationship } \\
r_{s}=0.049 ; p=0.581 ; n=132 \text { no relationship } \\
r_{s}=-0.153 ; p=0.259 ; n=56 \text { no relationship }\end{array}$ \\
\hline $\begin{array}{l}\text { Hypothesis 3: } \\
\text { There is relationship } \\
\text { between smartphones } \\
\text { market share and } \\
\text { inflation. }\end{array}$ & Android & $\begin{array}{l}\text { Confirmed } \\
\text { Confirmed } \\
\text { Rejected } \\
\text { Rejected } \\
\text { Rejected } \\
\text { Rejected } \\
\end{array}$ & $\begin{array}{l}\text { All } \\
\text { Developing } \\
\text { Developed } \\
\text { All } \\
\text { Developing } \\
\text { Developed }\end{array}$ & $\begin{array}{l}r_{s}=-0.313 ; p \leq 0.01 ; p=0.00 ; n=187 \text { (negative and moderate) } \\
r_{s}=-0.229 ; p \leq 0.01 ; p=0.08 ; n=131 \text { (negative and weak) } \\
r_{s}=-0.113 ; p=0.408 ; n=56 \text { no relationship } \\
r_{s}=-0.019 ; p=0.798 ; n=188 \text { no relationship } \\
r_{s}=-0.135 ; p=0.124 ; n=132 \text { no relationship } \\
r_{s}=-0.115 ; p=0.398 ; n=56 \text { no relationship }\end{array}$ \\
\hline $\begin{array}{l}\text { Hypothesis } 4 \text { : } \\
\text { There is relationship } \\
\text { between smartphone } \\
\text { market share and IDI } \\
\text { value. }\end{array}$ & Android & $\begin{array}{l}\text { Confirmed } \\
\text { Confirmed } \\
\text { Confirmed } \\
\text { Confirmed } \\
\text { Confirmed } \\
\text { Confirmed }\end{array}$ & $\begin{array}{l}\text { All } \\
\text { Developing } \\
\text { Developed } \\
\text { All }\end{array}$ & $\begin{array}{l}r_{s}=0.832 ; p \leq 0.01 ; p=0.00 ; n=174 \text { (positive and strong) } \\
r_{s}=0.752 ; p \leq 0.01 ; p=0.00 ; n=119 \text { (positive and moderate) } \\
r_{s}=0.779 ; p \leq 0.01 ; p=0.00 ; n=55 \text { (positive and strong) } \\
r_{s}=-0.142 ; p \leq 0.05 ; p=0.062 ; n=174 \text { (negative and very } \\
\text { weak) } \\
r_{s}=0.326 ; p \leq 0.01 ; p=0.00 ; n=119 \text { (positive and moderate) } \\
r_{s}=-0.657 ; p \leq 0.01 ; p=0.00 ; n=55 \text { (negative and strong) }\end{array}$ \\
\hline $\begin{array}{l}\text { Hypothesis 5: } \\
\text { There is relationship } \\
\text { between smartphone } \\
\text { market share and } \\
\text { Unemployment }\end{array}$ & Android & $\begin{array}{l}\text { Rejected } \\
\text { Rejected } \\
\text { Rejected } \\
\text { Confirmed } \\
\text { Rejected } \\
\text { Confirmed }\end{array}$ & $\begin{array}{l}\text { All } \\
\text { Developing } \\
\text { Developed } \\
\text { All } \\
\text { Developing } \\
\text { Developed } \\
\end{array}$ & $\begin{array}{l}r_{s}=-0.078 ; p=0.291 ; n=187 \text { no relationship } \\
r_{s}=-0.002 ; p=0.982 ; n=131 \text { no relationship } \\
r_{s}=-0.198 ; p=0.144 ; n=56 \text { no relationship } \\
r_{s}=0.206 ; p \leq 0.01 ; p=0.005 ; n=188 \text { (positive and very weak) } \\
r_{s}=0.167 ; p=0.056 ; n=132 \text { no relationship } \\
r_{s}=0.277 ; p \leq 0.05 ; p=0.039 ; n=56 \text { (positive and weak) }\end{array}$ \\
\hline $\begin{array}{l}\text { Hypothesis 6: } \\
\text { There is relationship } \\
\text { between smartphone } \\
\text { market share and HDI }\end{array}$ & Android & $\begin{array}{l}\text { Confirmed } \\
\text { Confirmed } \\
\text { Confirmed } \\
\text { Rejected } \\
\text { Confirmed } \\
\text { Confirmed }\end{array}$ & $\begin{array}{l}\text { All } \\
\text { Developing } \\
\text { Developed } \\
\text { All } \\
\text { Developing } \\
\text { Developed }\end{array}$ & $\begin{array}{l}r_{s}=0.779 ; p \leq 0.01 ; p=0.00 ; n=187 \text { (positive and strong) } \\
r_{s}=0.656 ; p \leq 0.01 ; p=0.00 ; n=131 \text { (positive and moderate) } \\
r_{s}=0.779 ; p \leq 0.01 ; p=0.00 ; n=56 \text { (positive and strong) } \\
r_{s}=-0.096 ; p=0.189 n=188 n \text { no any relationship } \\
r_{s}=0.390 ; p \leq 0.01 ; p=0.00 ; n=132 \text { (positive and moderate) } \\
r_{s}=-0.699 ; p \leq 0.01 ; p=0.00 ; n=56 \text { (negative and moderate) }\end{array}$ \\
\hline
\end{tabular}

Source: Own results based on research.

In Developing Countries, IDI value and Android market share are positively correlated $\left(\mathrm{r}_{\mathrm{s}}=0.326 ; \mathrm{p} \leq 0.01 ; \mathrm{p}=\right.$ $0.00 ; \mathrm{n}=119)$. The strength of the relationship is moderate. Moreover, the share of Android smartphones is high in the Developing Countries with low or average IDI (ICT access, use, and skills). For example, the Central African Republic, Eritrea, and Chad have the worst results for IDI in 2016 and Android market share in all these countries is higher than $70 \%$. Also, the first 12 countries with the lowest IDI value are Low-income countries. So, in poor countries with low-quality communication services the consumers prefer to use Androids. Consumers from developed countries with high IDI value prefer another OS instead of Android. Results of the analysis show a decreasing nonmonotonic association with medium/strong strength $\left(r_{s}=-0.657\right)$. From another side, the main competitor of Android OS is smartphones manufactured by Apple Inc. More likely, consumers from developed world prefer iPhones which also proved. In this case, the relationship is positive strong and significant $\left(\mathrm{r}_{\mathrm{s}}=\right.$ $0.779 ; \mathrm{p}=0.00 ; \mathrm{n}=55)$. 
Worldwide, the total percentage of unemployment in the country and the market share of Android smartphones correlated positively (Hypothesis 5). There is a very weak positive correlation with unemployment $\left(\mathrm{r}_{\mathrm{s}}=0.206\right.$ low enough to consider as not influential) however it is significant. Nevertheless, when countries are divided into two groups, results are different. There is no link between unemployment and Android market share in developing countries. In these countries, the smartphone purchase decision is not related to financial status but rather to a personal decision. In developed countries, the correlation between the percentage of the unemployed labor force and Android market share is positive and significant. However, the correlation coefficient is not strong $\left(r_{\mathrm{s}}=0.277\right)$. Unemployed individuals from developed countries prefer to buy a cheap handset at least until he/she will find a new job in order not to spend so much money.

Human Development Index is essential for current research as it contains information about education and life expectancy indices and GNI (Hypothesis 6). Worldwide there is no relationship between HDI and Androids' market share. Despite this, if countries are separated according to the moderator variable, results are different. In both cases, there is a significant relationship. HDI and share of Androids are positively correlated in Developing Countries. Correlation coefficient value is moderately high $\left(r_{s}=0.390\right)$. Hence, in the developing countries with better situation (average level of HDI - like Russia, Belarus etc.) consumers more likely will purchase Androids. In developed countries relationship between the above-mentioned variables are significant and strong. However, it is negative $\left(\mathrm{r}_{\mathrm{s}}=-0.699\right)$. High results of HDI go with the low rate of Android market share which defines decreasing nonmonotonic relationship.

\section{2 iOS}

Globally, in 2016 the relationship between iOS market share and GDP per capita was positive, strong and significant (Hypothesis 1). Correlation coefficient value is high $\left(r_{s}=0.728\right)$. It means that, higher GDP per capita increases the probability of consumers purchasing smartphones manufactured by Apple Inc. On the other hand, GDP per capita is a universal indicator which represents the economic power of the country. Logically, after segmenting the countries to developed and developing categories, results also remained significant. In the developing countries, which rely on the export of raw materials (that results in a low-level GDP), even if consumers could have enough amount of money to afford iPhone, uncertainty in the future and several other factors prevent it. Moreover, results were significant for these countries and the iOS market share is positively correlated with per capita GDP $\left(\mathrm{r}_{\mathrm{s}}=0.588 ; \mathrm{n}=130\right)$. So, individuals in better economic conditions prefer to use an iPhone instead of Android. In strong/developed economies (which also means high GDP per capita) consumers have high income and they feel confident about the future and it encourages them to purchase expensive products. Consequently, in this case, the relationship is strong, and the Correlation coefficient is high. $\left(\mathrm{r}_{\mathrm{s}}=0.703 ; \mathrm{n}=56\right)$

Results of the analysis show that generally Gross savings as the percentage of GDP (in 2016) are correlated with iOS market share (Hypothesis 2 ) however the correlation is weak $\left(r_{s}=0.228\right)$. It can be explained with the price of the smartphones designed by Apple Inc. By contrast, there is no any correlation between variables in the terms of developing/developed countries. As it was explained earlier, consumer's decision about purchasing an iPhone is mainly connected with the economic strength of the country rather than with the amount of individual savings. According to the results, basically, consumers do not prefer to use their saving in order to buy these smartphones or just a small amount of money could be added.

Inflation is the most important indicator to measure the price change of goods and services. High rates of inflation can be defined as a threat to the national economy. For the current analysis, inflation measured by CPI was used (Hypothesis 3). As high inflation level characterizes developing countries, it is evident that, there is a significant, negative $\left(r_{\mathrm{s}}=-0.302\right)$ and weak correlation between inflation and iPhone market share. The unstable economic situation in the countries created an environment where iPhones are sometimes expensive even for the middle-class consumers. For example, in oil-exporting former Soviet countries, oil price fell in 2014 and it caused national currency devaluation (for example in Russia, Kazakhstan, Turkmenistan, Azerbaijan). The changes affected the smartphone market, and the market share of Apple decreased by more than $10 \%$ during several months (between the 4th quarter of 2014 and the 1st quarter of 2015). Consequently, in the above-mentioned economic conditions and uncertainty about the future, the consumer will not decide to purchase iPhone. The mentioned situation can be supported by the results of the analysis which shows that inflation and iOS market share have a negative and weak correlation $\left(\mathrm{r}_{\mathrm{s}}=-0.229 ; \mathrm{n}=131\right)$. However, in a downturn or crisis period, the strength of the mentioned correlation can be high, and it has been already proven by results. Developed countries have a strong economy and the level of inflation is supporting the healthy development of the national economy. It is evident that, the iPhone market share is high in the mentioned countries, consumers personal income let them afford the price of the handsets. On the other side, governments 
are able to keep inflation on the level which enhances economic development.

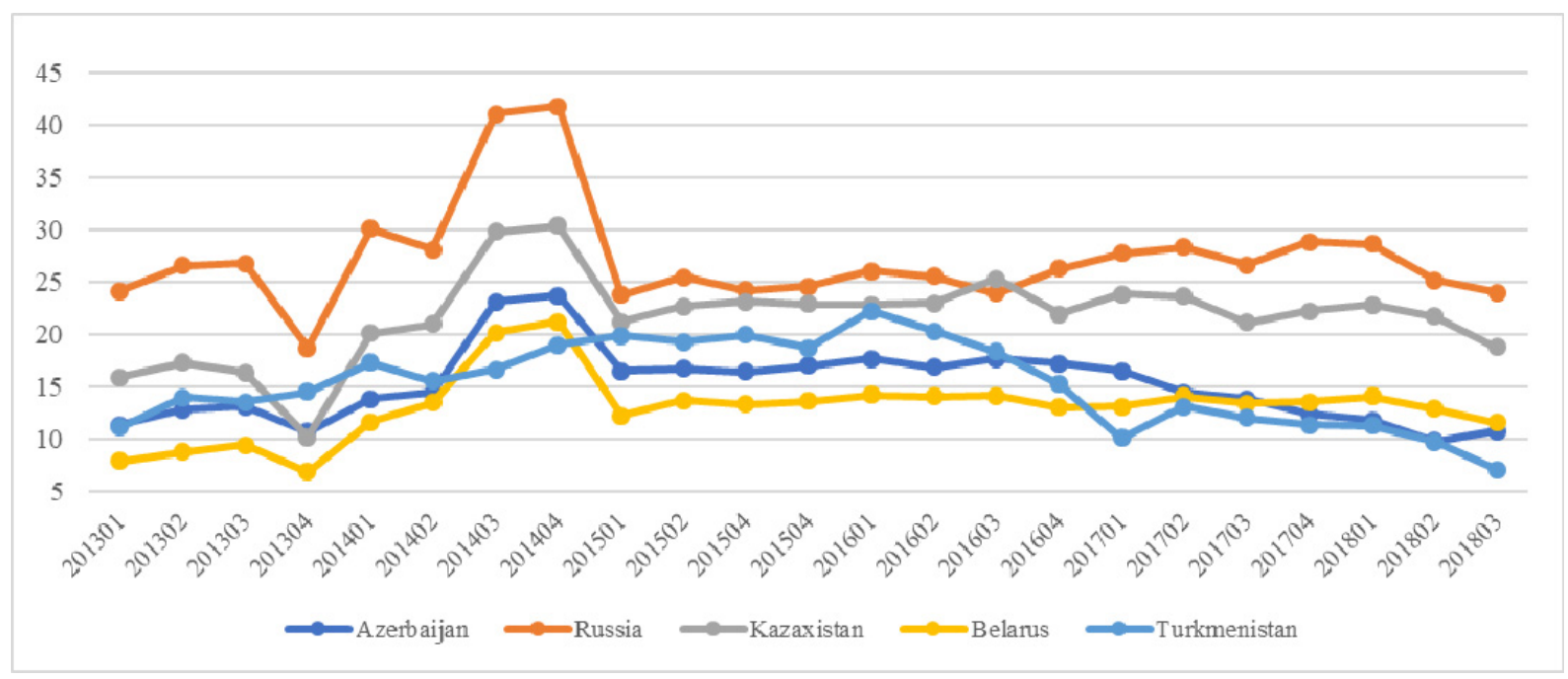

Figure 2. Per quarter iPhone market share from 2013-2018

Source: Own editing based on http://statcounter.com/.

Economic development of the country is also connected with the quality of the telecommunication services (Hypothesis 4). According to the results, worldwide iPhone market share and IDI value have a strong and positive relationship $\left(r_{s}=0.832 ; \mathrm{p}=0.00, \mathrm{n}=159\right)$. Logically, in developed countries, the IDI value is at the top. In 2016, South Korea, Iceland, Denmark, Switzerland had an extreme value of IDI. Excluding South Korea (market share of iOS around $20 \%$ ), at least around $40 \%$ of consumers of the first 10 countries with the highest IDI purchased iPhone in 2016. Results for developed countries showed a positive strong and significant relationship between variables $\left(\mathrm{r}_{\mathrm{s}}=0.779 ; \mathrm{n}=55\right)$. Developing countries as the Central African Republic, Eritrea, and Chad have the lowest rate of IDI and only 5\% of consumers could buy an iPhone. From another side, using the newest technologies also requires telecommunication infrastructure, and, in poor countries, with low indicators, it could be hardly possible. But even in this case, there is a quite strong and positive relationship between variables $\left(\mathrm{r}_{\mathrm{s}}=0.752 ; \mathrm{n}=119\right)$.

The situation regarding unemployment as a variable is different than in terms of the above-mentioned economic indicators (Hypothesis 5). In general, no relationship was observed between the ratio of unemployment and IOS based phones' market share neither in developed nor in developing regions $\left(r_{s}=-0.033 ; p=0.682, n=152\right)$. But also for developing and developed countries, the hypothesis was rejected. Consequently, occupation is not important in the case of iPhone purchase. The main idea is the following: when an unemployed person needs to buy the smartphone, he/she will try to make an optimal price/quality decision. Considering that the price of average smartphones is around $\$ 214$, a decision will be beside the cheap or medium price handset smartphone rather than iOS. The mentioned notion has already proven by the relationship between the Android market share and unemployment in the case of developed countries. After losing the job, if it is a necessity to buy a handset, consumers switch from expensive iOS or Androids to cheap Android smartphones.

From a development point of view, it is interesting to analyze the relationship between the Human Development Index and the iOS market share (Hypothesis 6). Worldwide, there is a strong and positive relationship between variables $\left(\mathrm{r}_{\mathrm{s}}=0.779 ; \mathrm{n}=187\right)$. Both have large values in developed countries and small in developing countries. So, they are directly proportional. For the Developing Countries, the strength of the relationship is moderate $\left(\mathrm{r}_{\mathrm{s}}=\right.$ $0.656 ; n=131$ ) while for developed countries it is enough (even if the sample size is small, $r_{s}=0.779 ; n=56$ ). It relates to the Human Development Index which represents life expectancy, education, and GNI.

\section{Managerial Implications}

\subsection{Android}

The demand for cheap smartphones increased the flourishing opportunities of low-priced Android-based smartphones. The target group is mainly people from less developed countries with low monthly income. These 
devices are affordable for them as they concentrate only basic functions and features. Android smartphones are the first need devices for being online or aware. Therefore, the purchasing power of handsets are not affected by inflation or gross savings whereas consumers are price sensitive. Also, Android's market share shows a weak correlation with unemployment all over the world. Despite that after implementing market segmentation no any relationship exists between the variables, because employment is one of the main ways of earning money. The strength of correlation between Human Development Index and Android market share is not strong. By reason of the mentioned relationship, Android users are people educated at middle-level with not so long lifespan.

$6.2 \mathrm{iOS}$

According to the result of the research at the macroeconomic level, there are some general characteristics of iPhone users. Most likely iPhone users are the consumers from developed countries with significantly high level of education and life expectancy. The outcomes showed that, in developed countries owners of the handsets are not price sensitive. Also, consumers partly use and invest their savings in purchasing smartphone. Occupation of the users has no any impact on their purchase intention worldwide. However, in emerging economies, the iPhone buyers are affected by economic changes and/or inflation at low level. As it has already been proven, the situation appear differently in crisis or downturn period. Interestingly, the target consumers of iOS-based smartphones in the third world are educated people with a longer lifespan. Considering the mentioned managerial implications during sales and in after-sales services would have good consequences for sellers.

\section{Measurement Problems and Limitations}

In economic research, it is unavoidable to have some limitations. There are several main limitations which have to be mentioned:

1) Sample size: the analysis includes 189 countries and 1 free economic area. Mainly these are the countries which provide their IDI value on an annual basis. Moreover, around 30 countries are missing from the analysis. They are small countries (for example, some islands) and/or less developed countries which have no IDI value. After using the moderator variable, the quantity of the countries which are considered as developed is only 56 . So, it is not a very large sample for analysis.

2) Countries were separated to 'developed' and 'developing' categories based on the World Bank's classification of countries regarding income level. It can face criticism, however, there are several classifications of the countries. The aim of the paper was to analyze the relationship between mobile phone purchase intention and the other socioeconomic variables, so the above-mentioned classification can be acceptable for this aim.

3) Year of analysis: results are concluded from the analysis of the data of 2016. It means that, some seasonal or yearly fluctuations, price changes and impact of the global trends can make a difference.

4) Data collection: used data belong to several sources, such as UN Comtrade, ITU, the World Bank databases and Statcounter website. The limitation also could be expressed as for some countries there is no evident data in any of these databases. It makes the sample size smaller which affects the results of the research.

5) Micro-level indicators such as cultural, social, personal and psychological factors are more effective in the context of different countries, however, the aim of the paper is to define general tendencies in the smartphone market.

\section{Conclusion}

Consumer behavior is a field examining attitudes toward the product, different kind of influences (needs/wants and other personal, psychological, social etc.) and altogether purchase process at the micro level. From an economic, infrastructural and self-development points of view, GDP per capita, IDI and HDI are crucial indicators in smartphone purchase. However, gross savings, inflation, and unemployment were not so important macroeconomic indicators affecting smartphone purchase.

IDI value and GDP per capita created the more evident picture of innovation diffusion level in 2016. The diffusion of innovations is fast in the case of iPhone users in the developed countries and wealthy people from developing countries. Due to political instability, dependency on raw material export, a weak economy, and poverty aggravated by the lack of employment and proper education, most of smartphone users can only afford cheap devices in developing economies.

People from countries with high HD index prefer to use smartphones designed by Apple Inc., unlike users from the emerging world. Androids sold and used in developed countries are not in the same price range with Androids in developing countries. High-middle or premium class Androids are designed for middle class and competing with iPhones. Androids use the same applications, are well designed to have good photo/video 
making features. Further researches will be focused on the defining of the reasons of cultural, economic and social differences in smartphone purchase behavior.

\section{References}

Abdel-Wahab, A. G., \& El-Masry, A. A. A. (2011). Mobile information communication technologies adoption in developing countries: Effects and implications. IGI Global. https://doi.org/10.4018/978-1-61692-818-6

Aker, J. C., \& Mbiti, I. M. (2010). Mobile phones and economic development in Africa. Journal of Economic Perspectives, 24(3), 207-232. https://doi.org/10.1257/jep.24.3.207

Apple Inc. (2018). Apple Inc. For the Fiscal Year Ended September 29, 2018, 15.

Arpaci, I., Cetin, Y. Y., \& Turetken, O. (2015). A cross-cultural analysis of smartphone adoption by canadian and Turkish organizations. Journal of Global Information Technology Management, 18(3), 214-238. https://doi.org/10.1080/1097198X.2015.1080052

Azariadis, C., \& Drazen, A. (1990). Threshold externalities in economic development. The Quarterly Journal of Economics, 105(2), 501-526. https://doi.org/10.2307/2937797

Bálint, C., \& Tóth, T. (2018). Economic approaches in the interpretation of sustainable development. In L. P. Kitti Némedi-Kollár, Zsuzsanna Kassai (Ed.), The examination of key factors of social and economic development in Hungary (p. 143). Gödöllő: Szent István Egyetemi Kiadó.

Bento, N. (2012). Historical diffusion of mobile phones and its impact on energy demand: Findings and outlook. IR-12-007. Retrieved from www.iiasa.ac.at

Bresnahan, T., \& Greenstein, S. (2014). Mobile computing: The next platform rivalry. American Economic Review, 104(5), 475-480. https://doi.org/10.1257/aer.104.5.475

Dedrick, J., \& Kraemer, K. (2017). Intangible assets and value capture in global value chains: The smartphone industry. World Intellectual Property Organization-Economics and Statistics Division.

Deutschmann, P. J., \& Danielson, W. A. (1960). Diffusion of knowledge of the major news story. Journalism Quarterly, 37(3), 345-355. https://doi.org/10.1177/107769906003700301

Dobrota, M., Jeremic, V., \& Markovic, A. (2012). A new perspective on the ICT Development Index. Information Development, 28(4), 271-280. https://doi.org/10.1177/0266666912446497

Domar, E. D. (1946). Capital expansion, rate of growth, and employment. Econometrica. Journal of the Econometric Society, 137-147. https://doi.org/10.2307/1905364

Donner, J. (2009). Blurring livelihoods and lives: The social uses of mobile phones and socioeconomic development. Innovations: Technology, Governance, Globalization, 4(1), 91-101. https://doi.org/10.1162/itgg.2009.4.1.91

Dyer-Witheford, N. (2015). Cyber-Proletariat. Pluto Press. https://doi.org/10.2307/j.ctt183p1zg

Fenn, J. (2013). Mobile Communication, by Rich Ling and Jonathan Donner. New Directions in Folklore, 11(1), $62-64$.

Galib, M. H., Hammou, K. A., \& Steiger, J. (2018). Predicting Consumer Behavior: An Extension of Technology Acceptance Model. International Journal of Marketing Studies, 10. https://doi.org/10.5539/ijms.v10n3p73

Griffin, K. (1970). Foreign capital, domestic savings and economic development. Bulletin of the Oxford University Institute of Economics \& $\quad$ Statistics, 32(2), 99-112. https://doi.org/10.1111/j.1468-0084.1970.mp32002002.x

Gruber, H., Koutroumpis, P., Mayer, T., \& Nocke, V. (2011). Mobile telecommunications and the impact on economic development. Economic Policy, 26(67), 387-426. https://doi.org/10.1111/j.1468-0327.2011.00266.x

GSMA. (2017). Accelerating affordable smartphone ownership in emerging markets. Retrieved from https://www.gsma.com/

GSMA. (2018a). The Mobile Economy. GSMA Intelligence, 50, 11-11. https://doi.org/10.5121/ijcsit.2015.7409

GSMA. (2018b). The Mobile Economy Sub-Saharan Africa 2018. GSMA Intelligence, 50.

Hazlett, T. W. (2011). Modular Confines of Mobile Networks: Are iPhones iPhony? Supreme Court Economic Review, 19(1), 67-102. https://doi.org/10.1086/664563 
IDC. (2017). Worldwide Mobile Phone Tracker, 2017. Boston, MA.

Jamalova, M., \& Fehér, I. (2018). Consumer Behavior. In I. Fehér (Ed.), Principles of Agrimarketing (pp. 154-171). Gödöllö: Szent István Egyetemi Kiadó.

James, J. (2012). The ICT Development Index and the digital divide: How are they related? Technological Forecasting and Social Change, 79(3), 587-594. https://doi.org/10.1016/j.techfore.2011.08.010

James, J. (2014). Patterns of mobile phone use in developing countries: Evidence from Africa. Social Indicators Research, $119(2), 687-704$. https://doi.org/10.1007/s11205-013-0510-9

James, J. (2015). The impact of mobile phones on poverty and inequality in developing countries. Springer. https://doi.org/10.1007/978-3-319-27368-6

Kalba, K. (2008). The adoption of mobile phones in emerging markets: Global diffusion and the rural challenge. International Journal of Communication, 2, 31.

Karjaluoto, H., Karvonen, J., Kesti, M., Koivumäki, T., Manninen, M., Pakola, J., ... Salo, J. (2005). Factors affecting consumer choice of mobile phones: Two studies from Finland. Journal of Euromarketing, 14(3), 59-82. https://doi.org/10.1300/J037v14n03_04

López-Nicolás, C., Molina-Castillo, F. J., \& Bouwman, H. (2008). An assessment of advanced mobile services acceptance: Contributions from TAM and diffusion theory models. Information \& Management, 45(6), 359-364. https://doi.org/10.1016/j.im.2008.05.001

Mackay, M. M., \& Weidlich, O. (2014). Australian mobile phone lifestyle index. Australia: AIMIA-The Digital Industry Association of Australia.

Njoh, A. J. (2018). The relationship between modern Information and Communications Technologies (ICTs) and development in Africa. Utilities Policy, 50(April), 83-90. https://doi.org/10.1016/j.jup.2017.10.005

Pádraig, C. (2012). The Informationalization of Poverty in Africa? Mobile Phones and Economic Structure. Open Journal Systems, 8(3), 1-17. $\quad$ Retrieved from http://www.itidjournal.org/index.php/itid/article/view/911

Park, Y., \& Chen, J. V. (2007). Acceptance and adoption of the innovative use of smartphone. Industrial Management and Data Systems, 107(9), 1349-1365. https://doi.org/10.1108/02635570710834009

Reid, A. J. (2018). Smartphone Paradox. Springer. https://doi.org/10.1007/978-3-319-94319-0

Rogers, E. M. (2003). The diffusion of innovation (5th ed.). New York: Free Press.

Roller, L.-H., \& Waverman, L. (2001). Telecommunications infrastructure and economic development: A simultaneous approach. American Economic Review, 91(4), 909-923. https://doi.org/https://doi.org/10.1257/aer.91.4.909

Samsung Electronics. (2017). Samsung Electronics Sustainability Report 2017. Seoul, Korea.

ScientiaMobile. (2016). Mobile Overview Report October - December 2016.

ScientiaMobile. (2016a). Mobile Overview Report April - June 2016.

ScientiaMobile. (2016b). Mobile Overview Report January - March 2016.

ScientiaMobile. (2016c). Mobile Overview Report July-September 2016.

ScientiaMobile. (2017a). Mobile Overview Report April - June 2017.

ScientiaMobile. (2017b). Mobile Overview Report January - March 2017.

ScientiaMobile. (2018a). Mobile Overview Report April - June 2018.

ScientiaMobile. (2018b). Mobile Overview Report January - March 2018.

ScientiaMobile. (2018c). Mobile Overview Report July-September 2018.

Sullivan, N. P. (2007). You can hear me now: how microloans and cell phones are connecting the world's poor to the global economy. John Wiley \& Sons. https://doi.org/https://doi.org/10.5860/choice.45-3313

Todaro, M. P., \& Smith, S. C. (2015). Economic Development Twelfth Edition (12th ed.). Pearson.

Waverman, L., Meschi, M., \& Fuss, M. (2005). The impact of telecoms on economic growth in developing countries. The Vodafone Policy Paper Series, 2(03), 10-24.

World Bank. (2008). Global economic prospects: Technology diffusion in the developing world. World bank. 


\section{Copyrights}

Copyright for this article is retained by the author, with first publication rights granted to the journal.

This is an open-access article distributed under the terms and conditions of the Creative Commons Attribution license (http://creativecommons.org/licenses/by/4.0/). 